\title{
Identifying and Criticizing the View of "Sum of Sayings" in Tafsīr-i Nimūneh (Case Study: Juz' 20 to 30)
}

\author{
Shams al-Huda Karami Asfah ${ }^{1}$; Asghar Hadavi ${ }^{2}$ \\ ${ }^{1}$ M.A. in Qur'an and Hadith Sciences, Shahed University, Tehran, Iran \\ hxkarami@gmail.com \\ ${ }^{2}$ Assistant Professor of Qur'an and Hadith Sciences, Shahed University, Tehran, Iran \\ hadavi@shahed.ac.ir
}

http://dx.doi.org/10.18415/ijmmu.v8i9.2902

\begin{abstract}
The sum of sayings includes gathering the opinions of other commentators on a subject that is very common in some interpretations, including Tafsīr-i Nimūneh. A phenomenon that has been repeatedly addressed throughout the development of Tafsīr-i Nimūneh. The purpose of this study is to study some verses of Tafsīr-i Nimūneh that bring the sayings and opinions of other commentators and has accepted all or some of them and considers the sum of them as unobstructed and then critique some of these verses based on three criteria of examining the concept of verse, the narrative examination and the lexical examination. Therefore, this research, with a descriptive-analytical method by studying documents, seeks to answer the question of how to identify and critique the view of "sum of sayings" in Tafsīr-i Nimūneh? The findings of the research indicated that 120 of the verses in this range had the acceptance of the sum of sayings, which by examining 81 of them with the studied interpretations, it was concluded that few of the verses were interpreted in other interpretations by the acceptance of sum of sayings. Although the sum of sayings can be seen in many verses, but different sayings have not been gathered here. Then, the aspects of the sum of the sayings were criticized in the three mentioned characteristics in a number of verses. The result was the justification of the sum of the sayings in some cases and the lack of justification in others.
\end{abstract}

Keyword: Interpretation of the Qur'an, Interpretive Methods of the Holy Qur'an, Makarem Shirazi, Critique; Sum of Sayings

\section{Introduction}

The Holy Qur'an, which is the source of human evolution, guides human beings to ultimate perfection with a simple and fluent expression. The interpretation of the Qur'an, followed by the critique of interpretations, is an important duty that brings us as close as possible to this important issue. The sum of sayings, which includes the opinion of other commentators, is seen in many different forms in many interpretations, and in Tafsīr-i Nimūneh, it has been repeatedly appeared in three forms:

1- Sum of sayings, about which the author does not give any opinion and is silent, which seems not to accept any of them.

2- Sum of sayings along with accepting one opinion and rejecting other opinions.

3- Sum of sayings in which two or more opinions are accepted and collecting them is possible. 
In this research, it is the third case that is reviewed in several ways. Most of them are interpretations that the author collects between two or more opinions, and the rest are cases that lead to the acceptance of the sum of sayings due to the wide meaning of the word or its instances. All these cases are 120 verses in the last ten Juz', 81 of which are compared with the five commentaries of Al-Mīzān, Majma' al-Bayān, Hadith, Taḥrīr and Al-Tanwīr, Rūh Al-Ma'ānī. For brevity, its results are reflected in Table (1) and only a few cases are given as detailed examples. Then, a number of verses under study were reviewed based on three characteristics of the studying the concept of the verse in comparison with the studied interpretations, lexical study in a number of dictionaries and validity critique. Accepting the sum of sayings in Tafsīr-i Nimūneh was justified if it had any of these three characteristics and could not be justified if it did not have any of the characteristics.

The five interpretations studied in comparison with the Tafsīr-i Nimūneh are divided into four forms, the result of which is presented in the form of columnar and circular diagrams (percent) in diagrams (1) to (5).

\section{2-Identifying the Sum of Sayings in a Few Verses and Comparing Them with Other Interpretations}

\section{2-1 The blessing of "appearance" and the blessing of "interior" (Luqmān: 20)}

Do ye not see that Allah has subjected to your (use) all things in the heavens and on earth, and has made His bounties flow to you in exceeding measure, (both) seen and unseen? Yet there are among men those who dispute about Allah, without knowledge and without guidance, and without a Book to enlighten them! (Luqmān/20)

Tafsīr-i Nimūneh: 1- The "appearance" is anything that cannot be denied to anyone, the creation and life and all kinds of daily bread and the "interior", is something that cannot be understood without accuracy. 2- The "appearance" is the organs of the body and the "interior" is the heart. 3- The "appearance" is beauty and upright stature and healthy limbs and the "interior" is the knowledge of God. 4- The "appearance" is Islam and the regular creation of man and sustenance, and the "interior" is to cover up the ugliness of deeds and to be disgraced in front of people. 5- The "appearance" is the knowledge of God and monotheism and the Prophet (PBUH) and the "interior" is the guardianship of the Ahl al-Bayt (PBUH) and the covenant of friendship with them. He goes on to write that there is no contradiction between interpretations, but each is an example (Makarem Shirazi, 1371: 17).

Tafsir Al-Mīzān: He knows the outward blessing as the outward senses such as eyes and ears, health, well-being and pure sustenance, and knows and states the inward blessings as abstract things, such as will and intellect, if the addressee of the verse is the polytheists. And if the addressee is all human beings, religion is added to the outward blessings and spiritual authorities are added to the inward blessings (Tabataba'i, 1374: 16/343).

Tafsir Majma' al-Bayān: He has mentioned all the cases that are in Tafsīr-i Nimūneh and in the end there may be no contradiction between the said sayings (Ṭabrasī, ns: 19/185 and 186).

Tafsir al-Hadith: Most of its cases are similar to Tafsīr-i Nimūneh (Darwazeh, 1421 AH: 4/256).

Tafsir Taḥrīr wa al-Tanwīr: The "appearance" is clear and the "interior" is hidden (Ibn Ashur, 1420 AH: 21/117).

Tafsir Rūh al-Ma'ānī: It has detailed all the points of Tafsīr-i Nimūneh without comment (Ālūsī, 1415 AH: 11/92 and 93). 
In Majma' al-Bayān and Rūh al-Ma'ānī, similar cases with Tafsīr-i Nimūneh have been given, but in al-Mīzān and Tafsir al-Taḥrīr, one meaning is sufficient.

\section{2-2 The Meaning of “Allah Merges Night Into Day and He Merges Day Into Night”(Luqmān/29)}

Seest thou not that Allah merges Night into Day and he merges Day into Night; that He has subjected the sun, and the moon (to His Law), each running its course for a term appointed; and that Allah is well-acquainted with all that ye do? (Luqmān/29)

Tafsīr-i Nimūneh: 1- Shortening and gradual increase of night and day during the year 2Conversion of day to night and night to day. The two interpretations do not contradict each other and may be both meanings are the same (Makarem Shirazi, 1371: 17 / 80)

Tafsir al-Mīzān: It expresses the first interpretation, with the testimony of the servant to the knowledge of God (Tabataba'i, 1374: 16/350).

Tafsir Majma' al-Bayān: It expresses both interpretations without comment (Ṭabrasī, nd: 19/195). Tafsir Tahrīr wa al-Tanwīr: Like al-Mīzān (Ibn Ashur, 1420 AH: 21/125).

Tafsir Rūh al-Ma’ānī: Like al-Mīzān (Ālūsī, 1415 AH: 11/100).

Among the interpretations under discussion, only Majma' al-Bayān, such as the Tafsīr-i Nimūneh, has two opinions, and in other cases, they just bring the first interpretation.

\section{2-3 Interpretation of "Some Have Submitted their Souls in Martyrdom” (Aḥzāb/23)}

"There are among the believers many Men who have been true to the covenant They made with Allah; of them some Have submitted their souls in Martyrdom; and there are some who are Waiting to join their brothers in Paradise and they have not in the least Changed their mind about their Covenant" (Aḥzāb/23)

Tafsīr-i Nimūneh: 1- Referring to the martyrs of Badr and Uhud 2- Referring to Hamza bin Abdul Muțallib and the rest of the martyrs of Uhud and Anas bin Nadr. He goes on to write that these interpretations do not contradict each other and the verse has a wide meaning (Makarem Shirazi, 1371: 24/176).

Tafsir al-Mīzān: It means the believers whose death has come (Tabataba'i, 1374: 16/435).

Majma 'al-Bayān: It has the same meaning of Tafsīr-i Nimūneh, without comment (TTabrasī, nd: 20/73).

Tafsir Tahrīr wa al-Tanwīr: It means the death of believers in jihad, which is metaphorical (Ibn Ashur, 1420 AH: 21/228).

Tafsir Rūh al-Ma'ānī: It is like Tafsīr-i Nimūneh, without comment (Ālūsī, 1421 AH: 11/167).

Al-Mizan mentioned the first meaning, al-Tahrīir wa al-Tanwīr defines it death in jihad, and the other two interpretations interpret it like Tafsīr-i Nimūneh.

\section{3-Table of Comparing Tafsïr-I Nimūneh with Other Interpretations in Verses of Sum of Sayings}

In comparing the Tafsīr-i Nimūneh with other interpretations, there were 4 modes, which include:

1- They have an idea similar to Tafsīr-i Nimūneh or have similar themes. 
2- They have a completely different opinion from the Tafsīr-i Nimūneh.

3- In some opinions, they are similar to Tafsīr-i Nimūneh. (That is, they have mentioned one or two cases of the sayings given in Tafsīr-i Nimūneh.

4- They have neither comment nor interpreted any verse (in cases where the idea of the interpreter is not given, it is because no comment is made or the verse has not been interpreted).

The above four forms were compared with the Tafsīr-i Nimūneh in five interpretations and the result was reflected in Table (1).

Table 1: Comparison of studied interpretations with Tafsīr-i Nimūneh

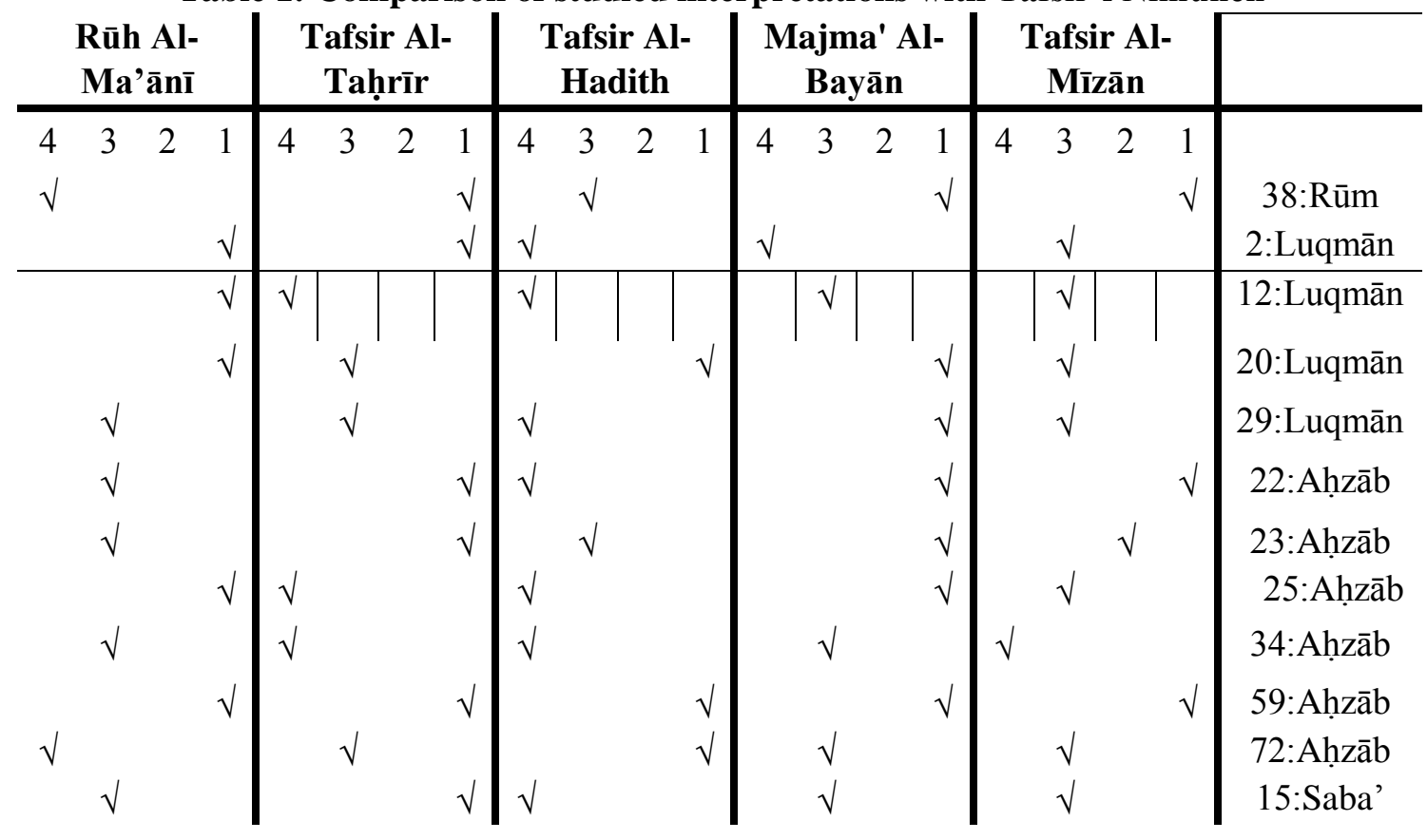

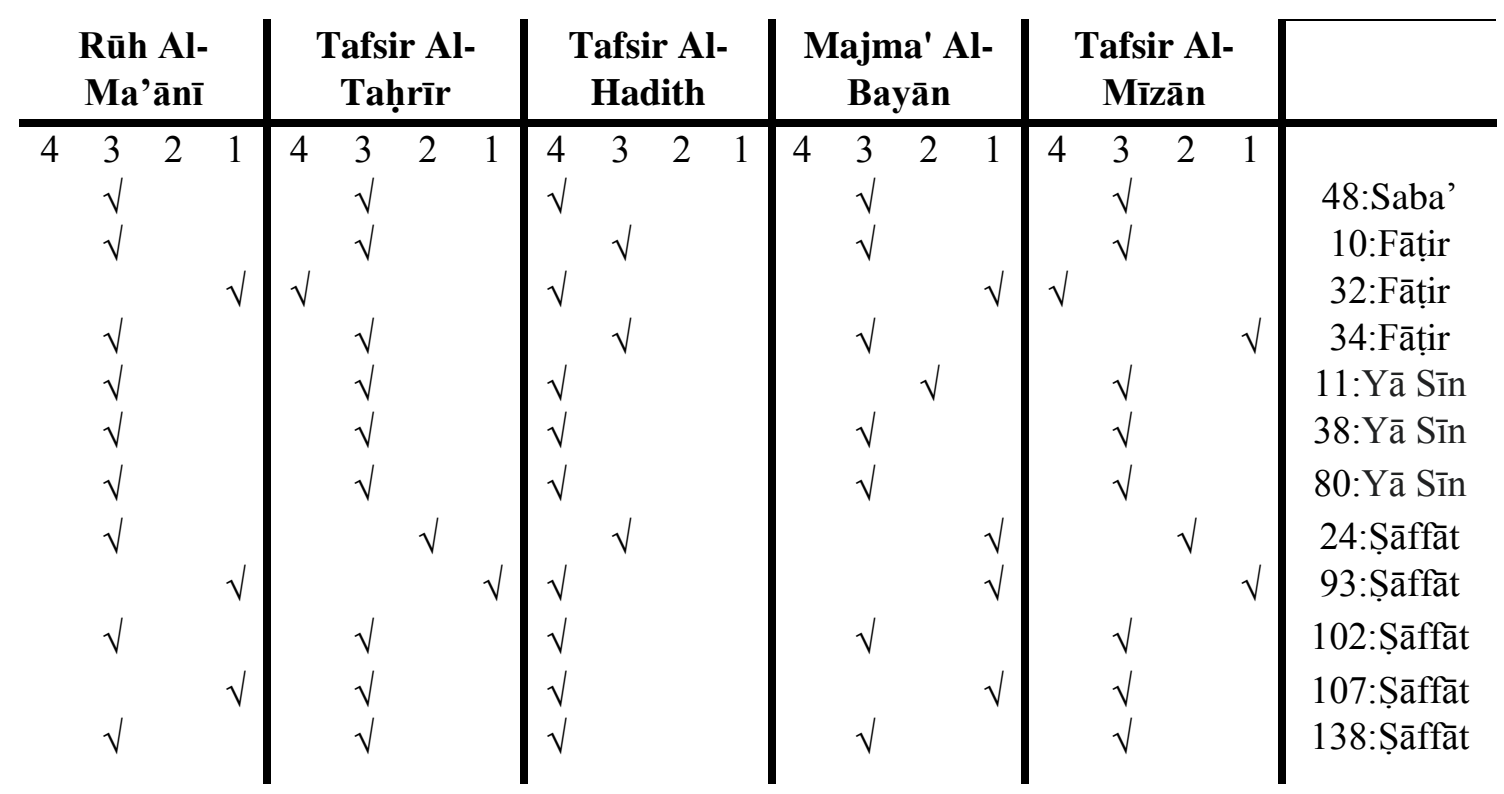




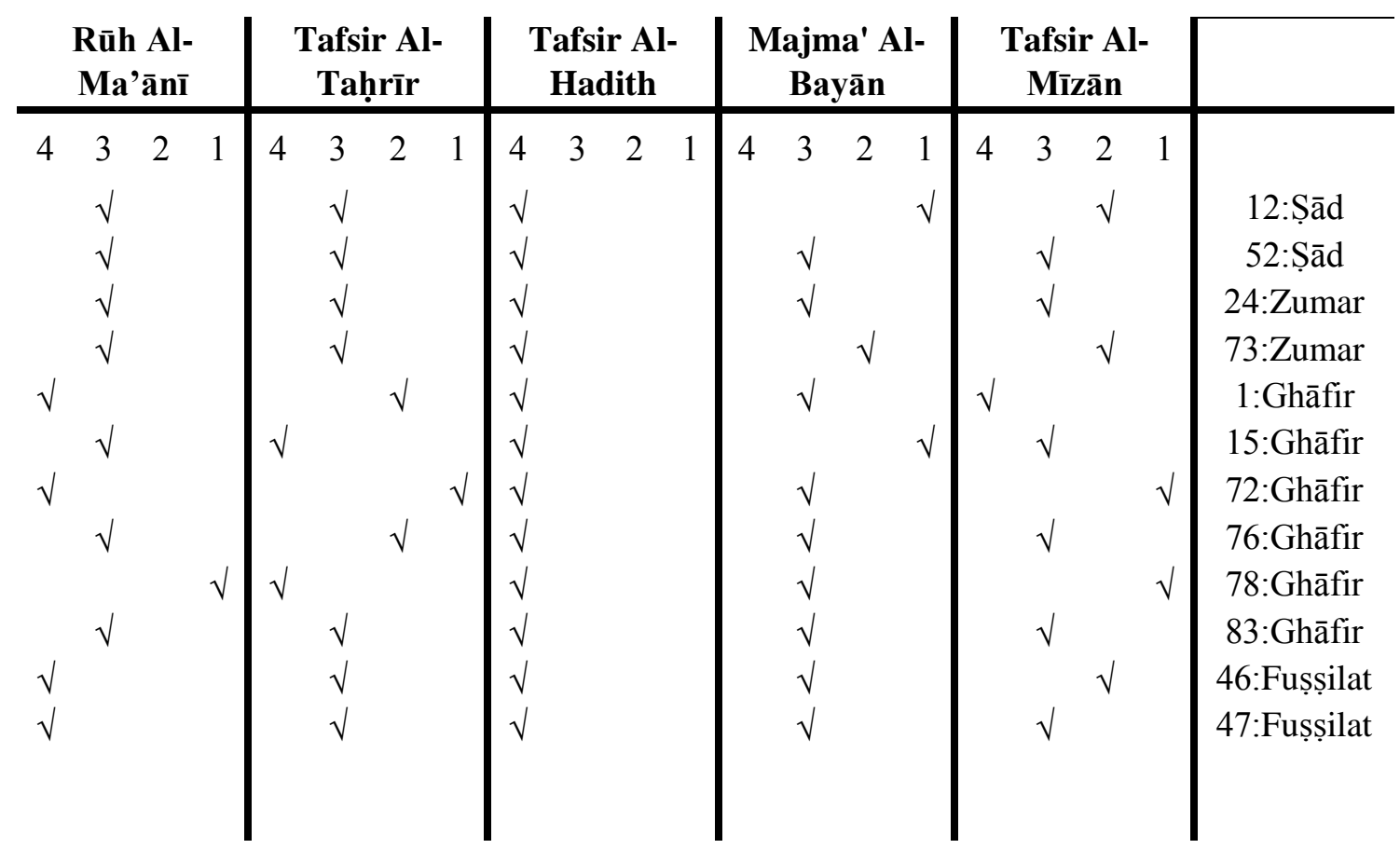

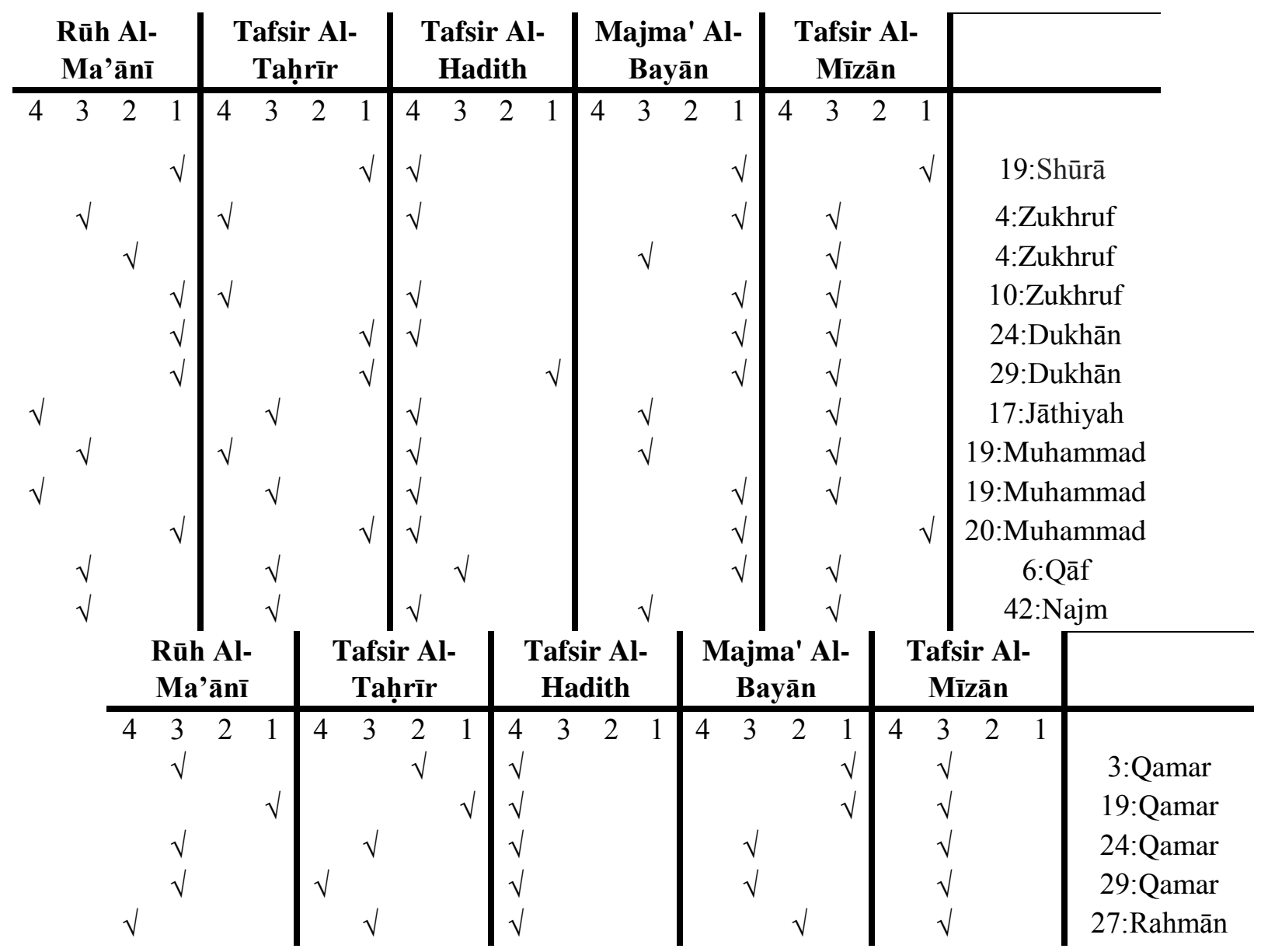




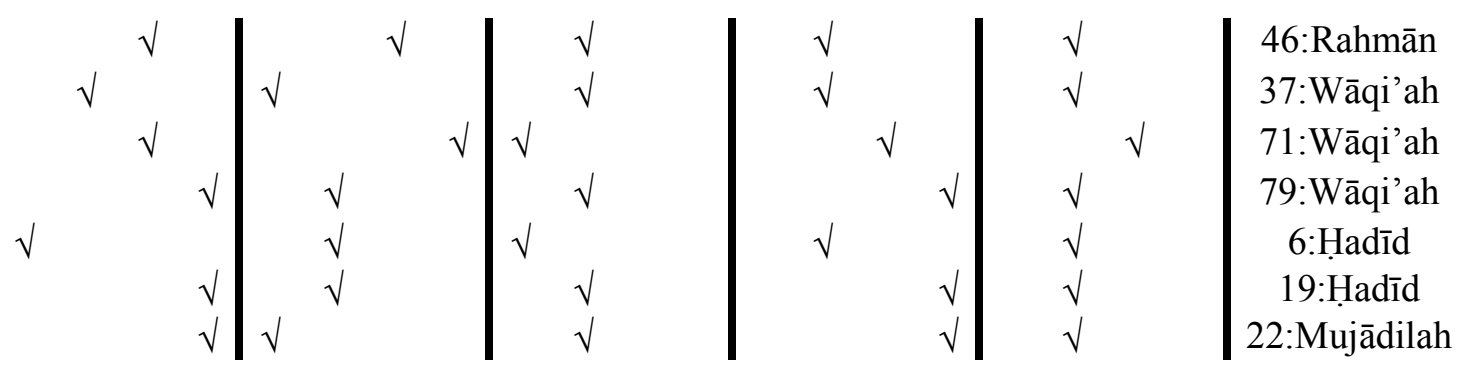

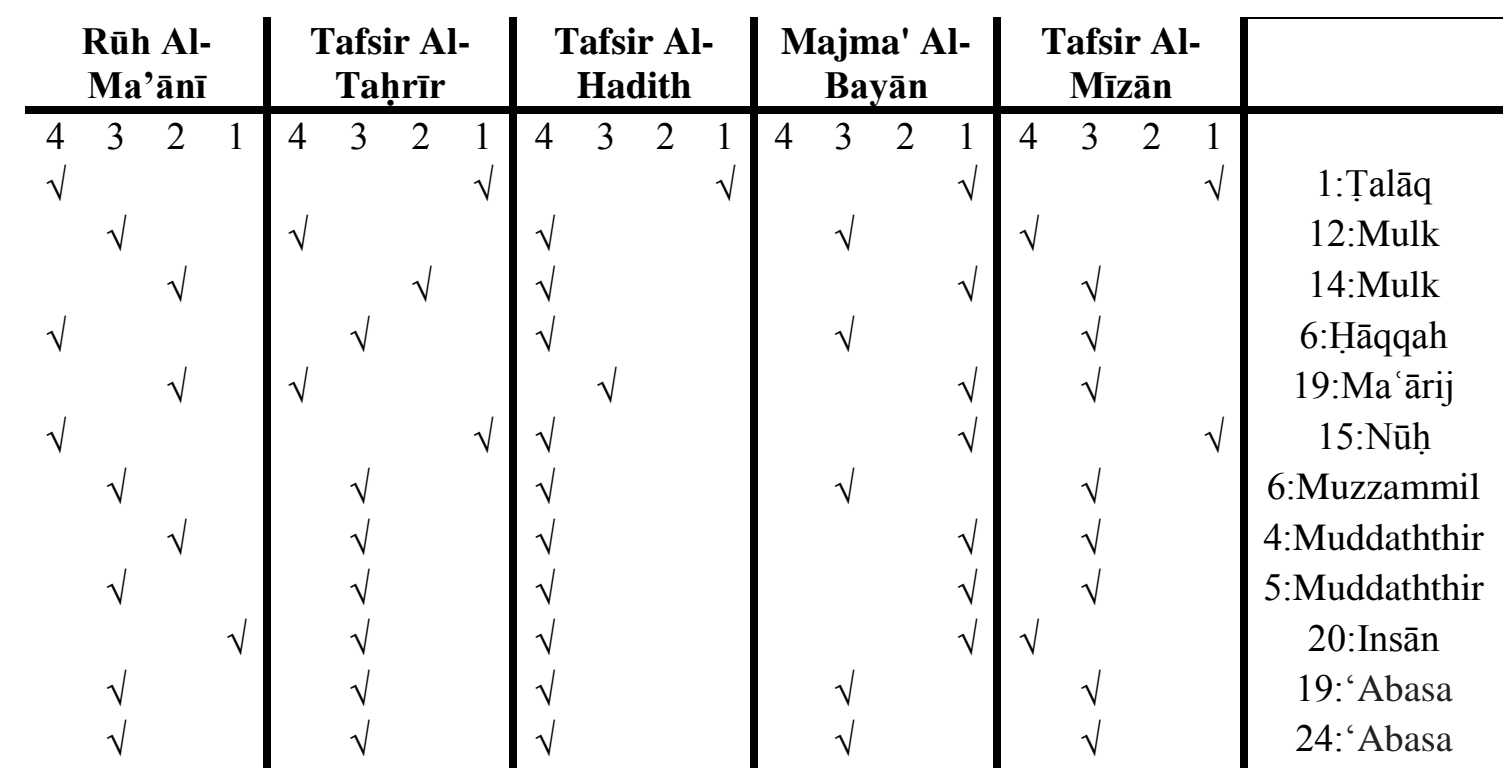

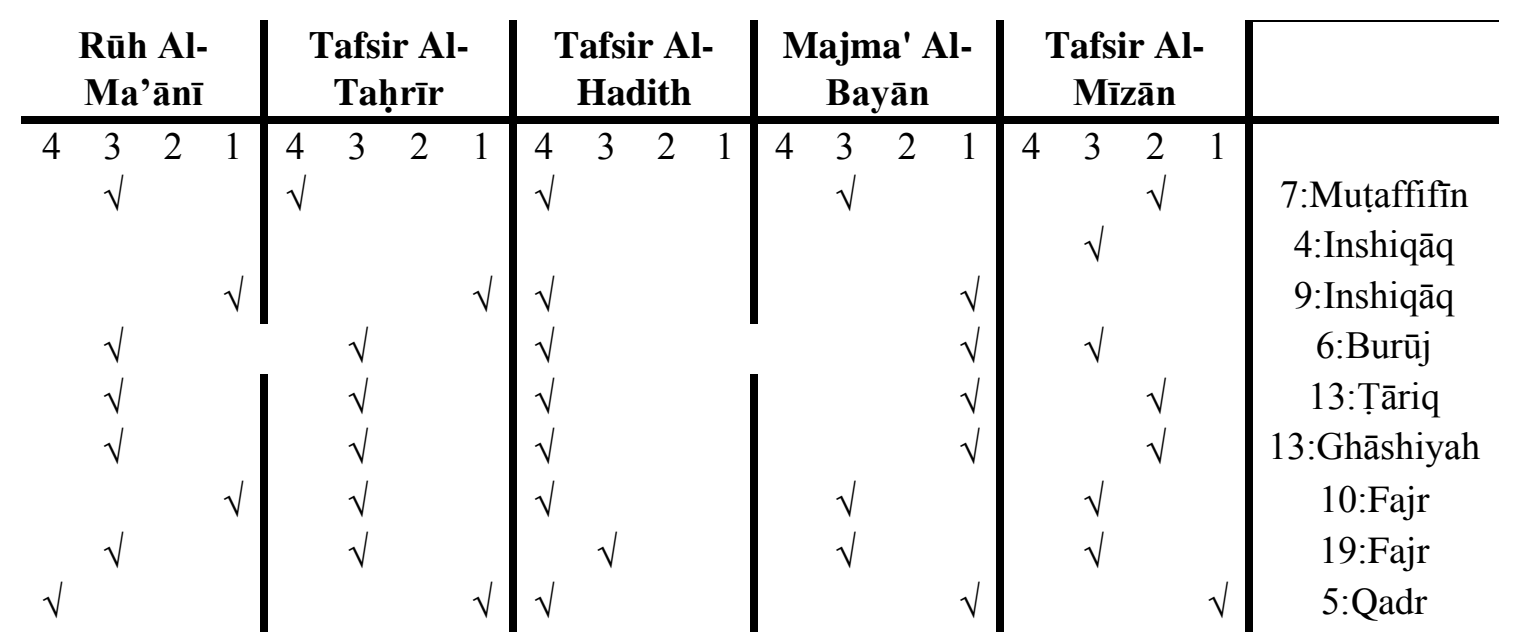




\section{Diagrams of Comparing Tafsīr-I Nimūneh with ther Interpretations}

\section{A) Tafsīr al-Mīzān}

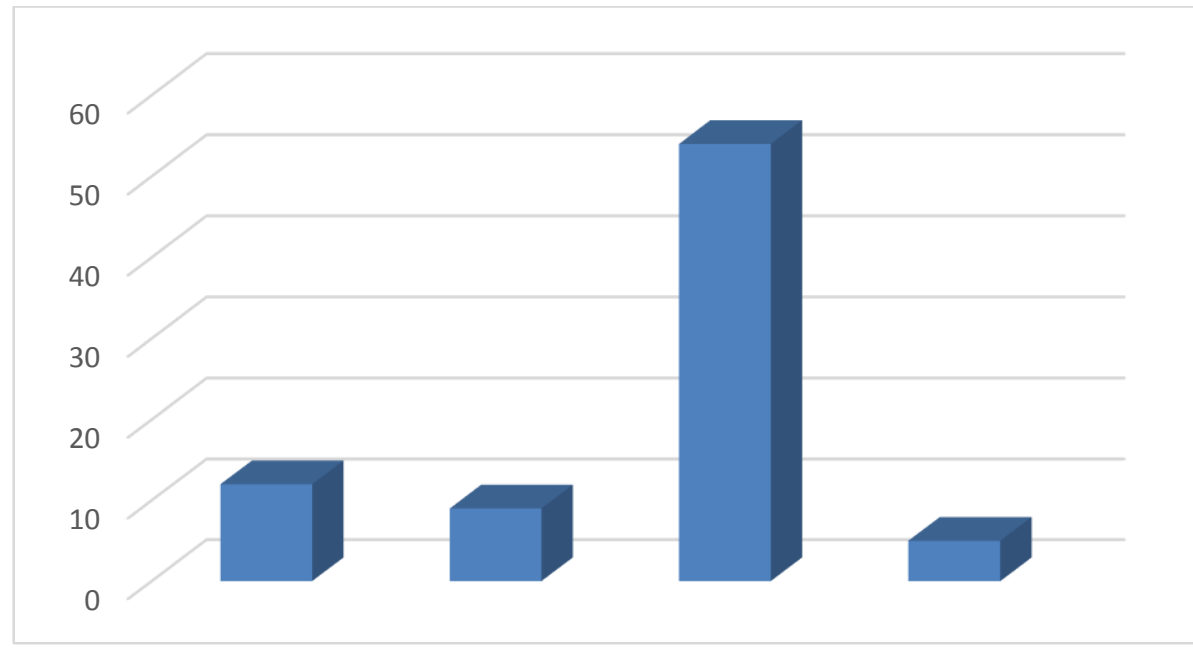

Agree with Disagree with some of the cases of without

Tafsīr-i Nimūneh Tafsīr-i Nimūneh Tafsīr-i Nimūneh comment

B)

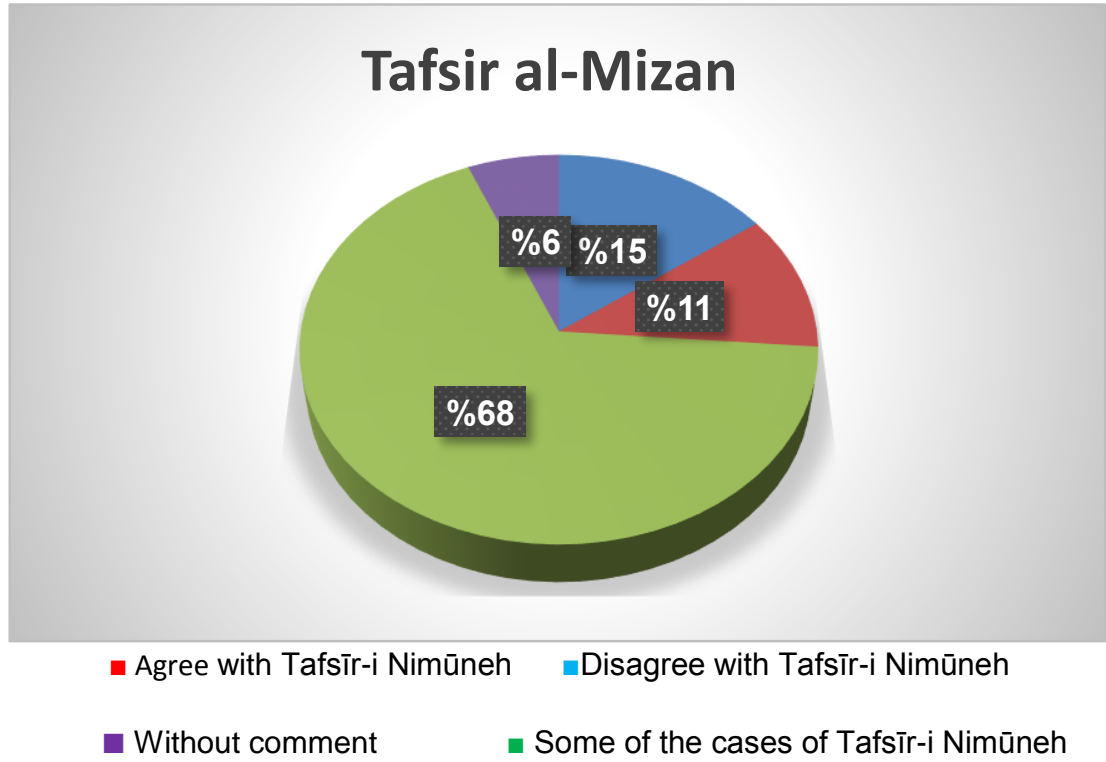

Diagram 1: Comparison of Tafsīr al-Mīzān with Tafsīr-i Nimūneh

a) Column chart b) Percentage chart 


\section{A) Majma al-Bayān}

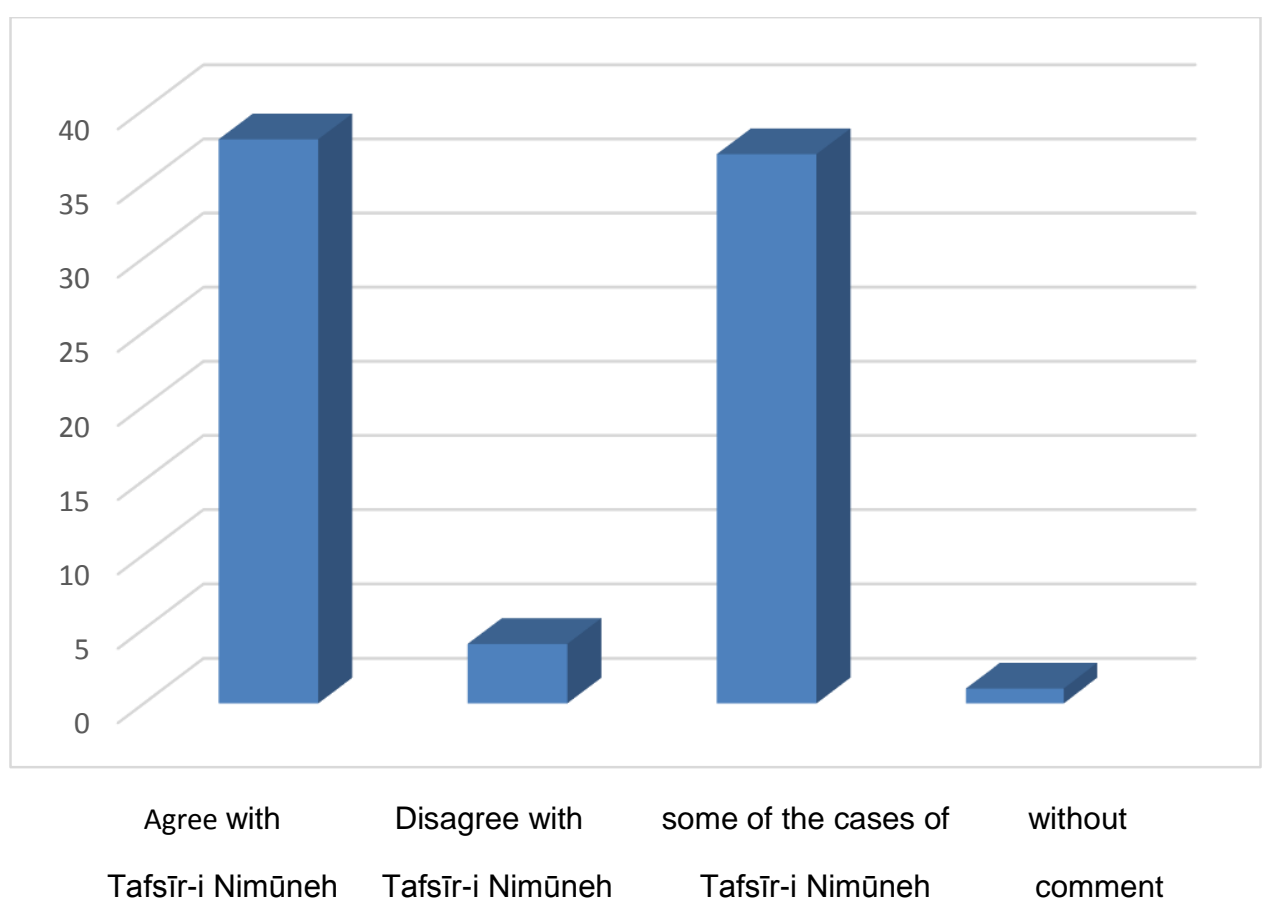

B) Majma al-Bayān

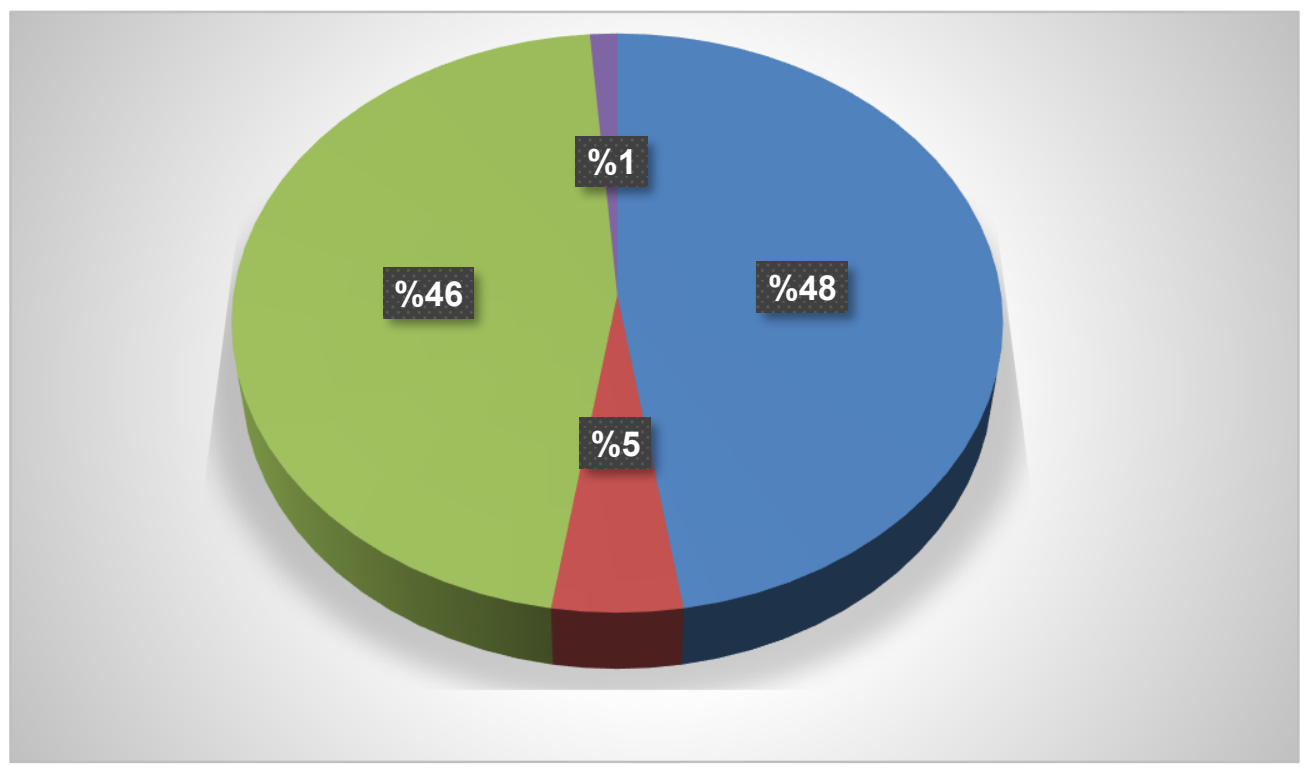

- Agree with Tafsīr-i Nimūneh घDisagree with Tafsīr-i Nimūneh

Without comment $\quad$ Some of the cases of Tafsīr-i Nimūneh

Diagram 2: Comparison of Tafsīr Majma al-Bayān with Tafsīr-i Nimūneh

a) Column chart b) Percentage chart 


\section{A) Tafsīr al-Hadith}

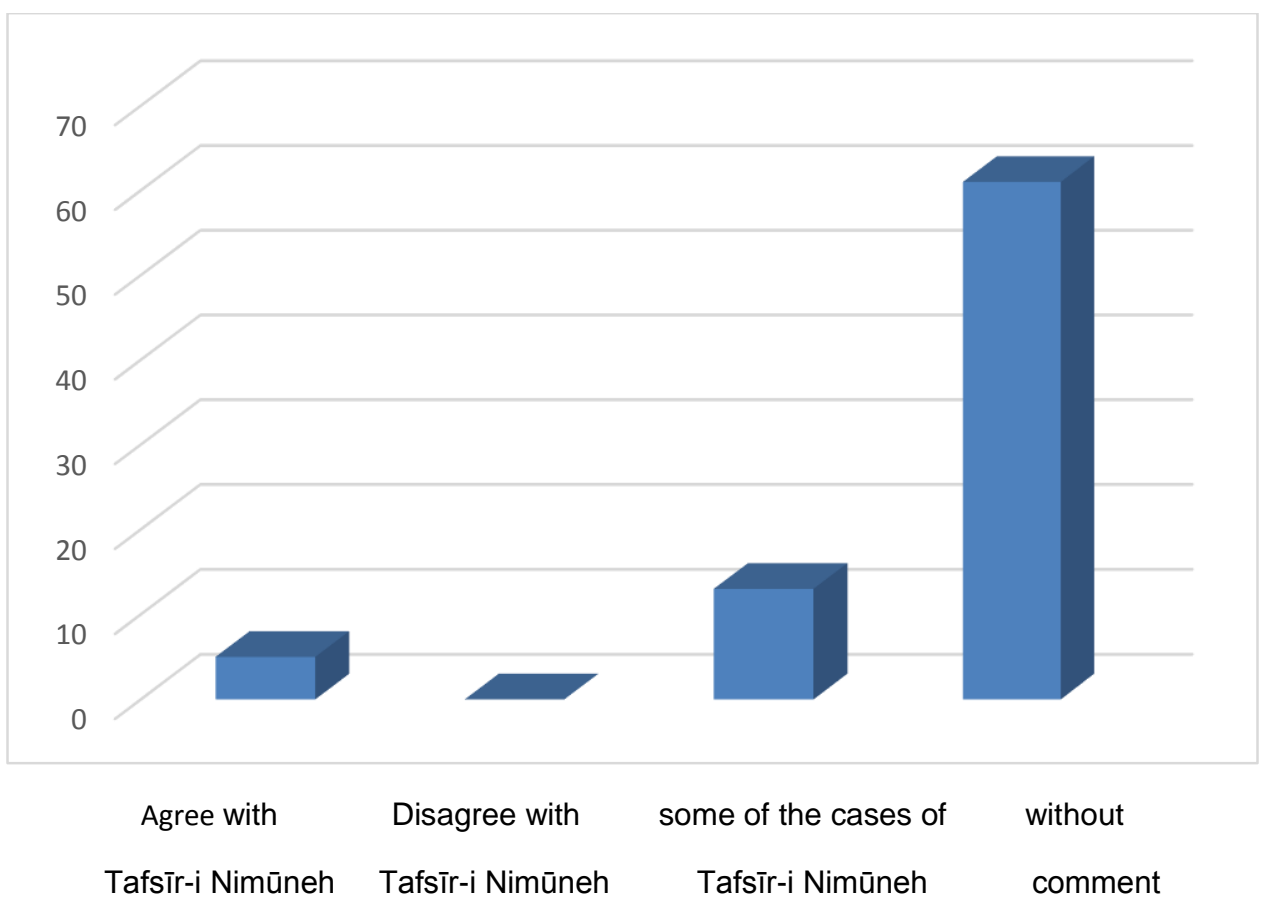

B) Tafsīr al-Hadith

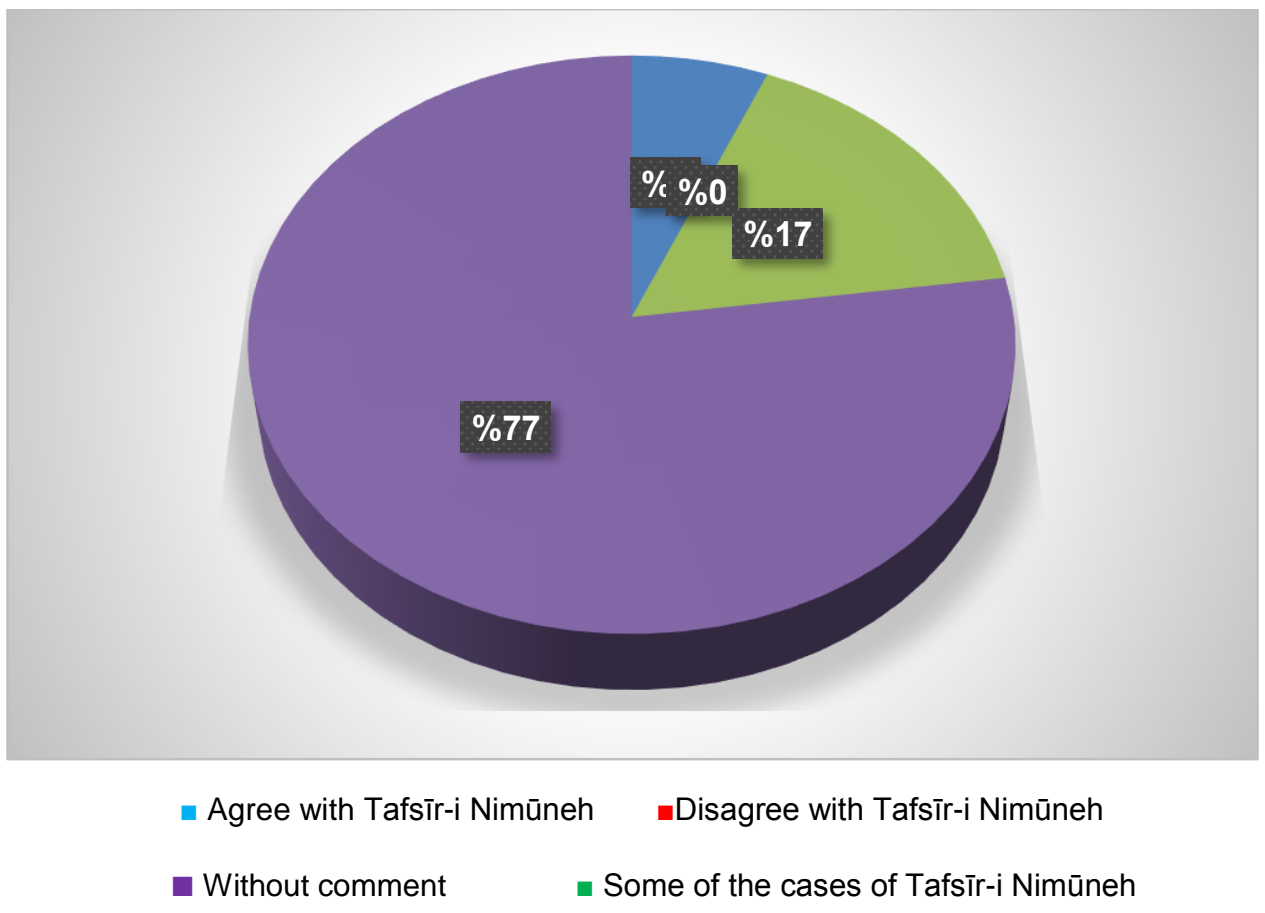

Diagram 3: Comparison of Tafsīr al-Hadith with Tafsīr-i Nimūneh

a) Column chart b) Percentage chart 


\section{A) Tafsir Al-Taḥrīr}

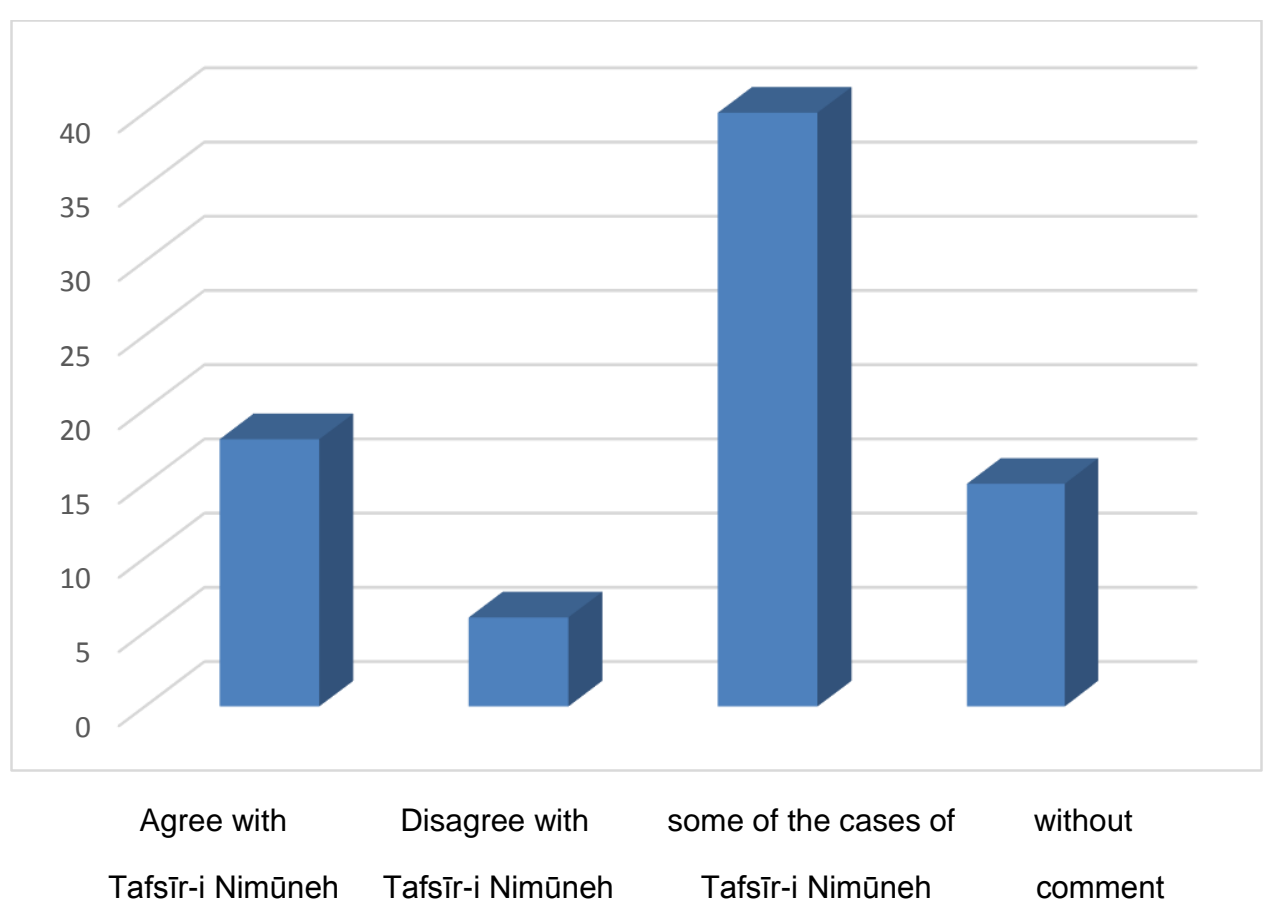

B) Tafsir Al-Taḥrīr

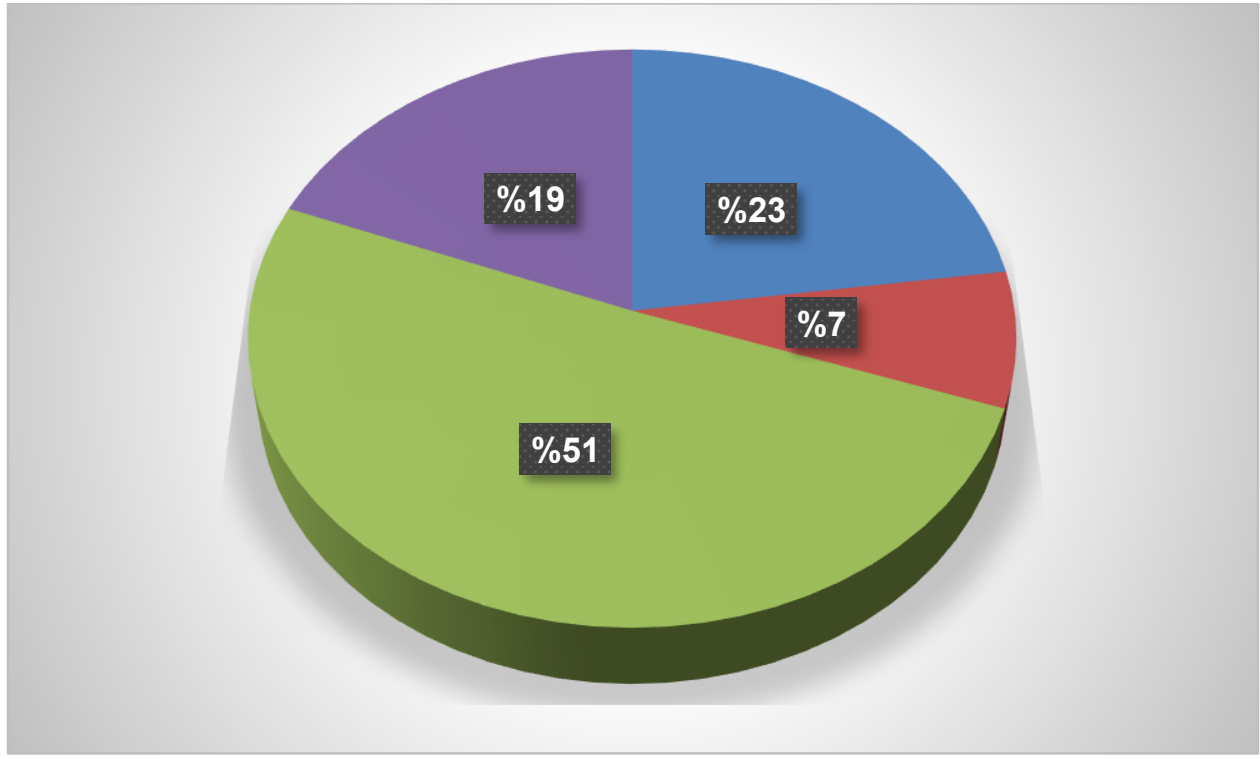

* Agree with Tafsīr-i Nimūneh

nDisagree with Tafsīr-i Nimūneh

* Some of the cases of Tafsīr-i Nimūneh

Without comment

Diagram 4: Comparison of Tafsir Al-Tahrīir with Tafsīr-i Nimūneh

a) Column chart b) Percentage chart 
A) Tafsir Rūh Al-Ma'ān̄̄

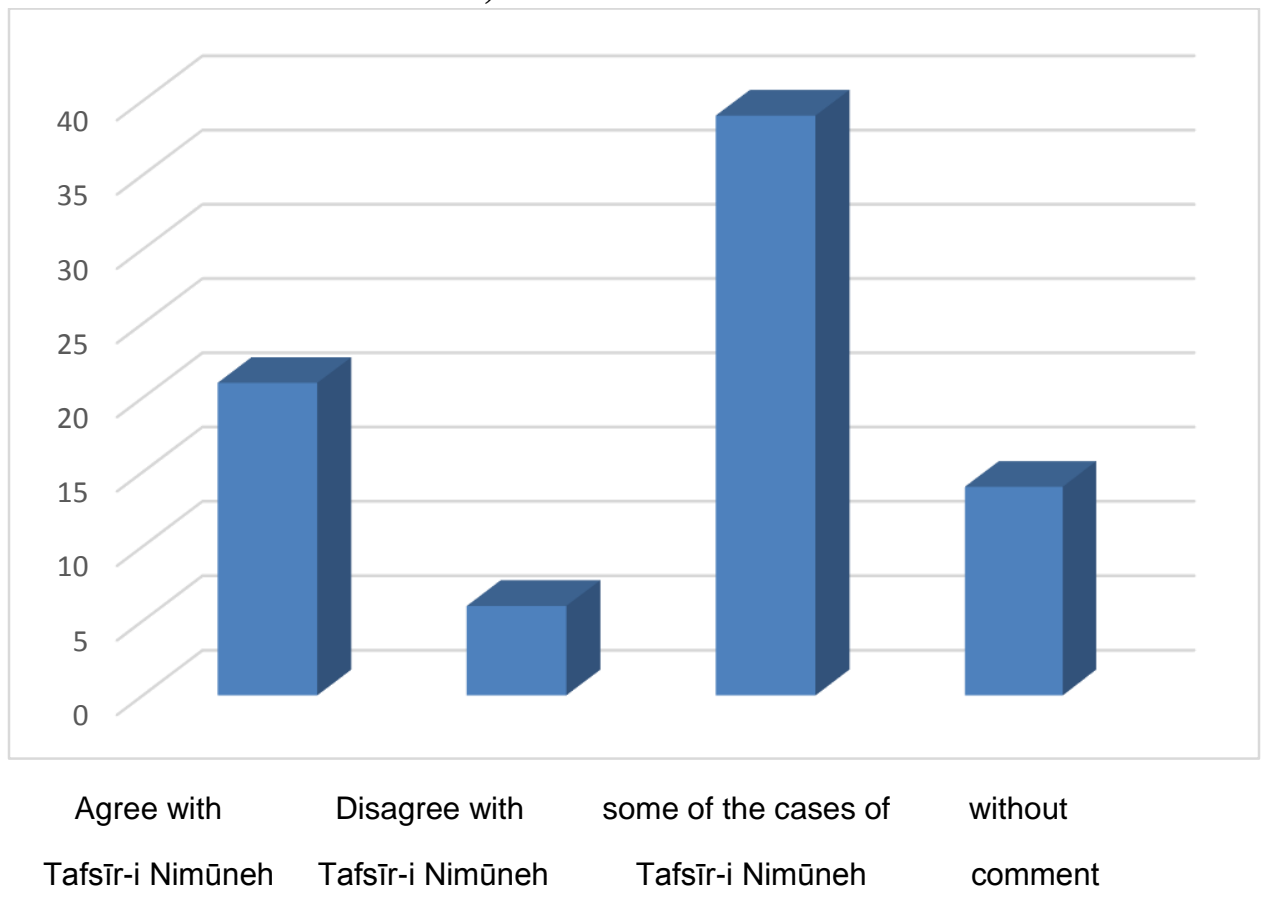

B) Tafsir Rūh Al-Ma'ān̄̄

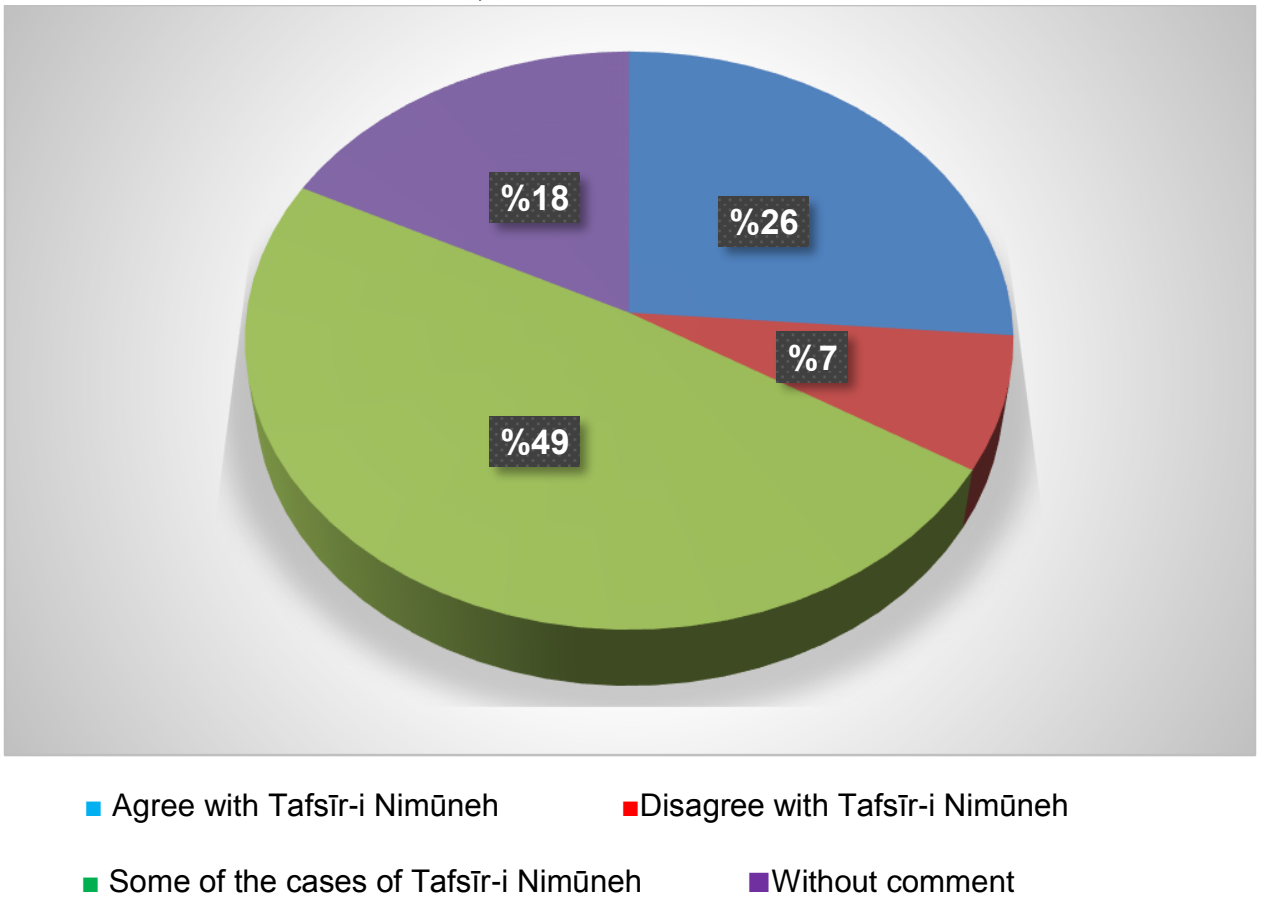

Diagram 5: Comparison of Tafsir Rūh Al-Ma'ānī with Tafsīr-i Nimūneh

b) Column chart b) Percentage chart 


\section{Critique of the Sum of Sayings in a Number of Verses in Tafsīr-I Nimūneh}

\section{5-1 Interpretation of the Verse "Say: Verily My Lord Doth Cast the Truth, He That Has Full Knowledge of (All) That Is Hidden.” (Saba'/48)}

\section{Examining the concept of the verse}

Tafsīr-i Nimūneh writes that there are several interpretations for this verse that can be combined.

1- Throwing the truth means throwing revelation and divine books on the hearts of the prophets, because God, by being aware of the hearts, knows the ready hearts and reveals to them, citing the famous hadith "Science is the light that God sheds on the hearts of those who want and see them deserved."

2- Another group has said that the purpose is to throw the right over the wrong and to beat and destroy the wrong by the right. That is, the truth removes the obstacles and no one can face it, and this is a threat to the opponents to know that the Qur'an is the truth and not to face it. They are cited in Surah Anbiyā', verse 18.

3- It is possible that the meaning of "Qadhf" is the influence of the legitimacy of the Qur'an in all parts of the world and the spread of divine revelation, which is confirmed by the next verse (Makarem Shirazi, 1371: 18/147).

In Tafsīr al-Mīzān, based on the context of the previous verses, he considers the meaning of "Qadhf" to be the revelation of the Qur'an to the Messenger of God and states that the following verses confirm this. (Tabataba'i, 1374: 16/586).

Tafsīr Majma' al-Bayān, like al-Mīzān, suffices in one sense, and quotes the commentary of Qatādah and Maqātil as Allameh. He seems to have accepted this opinion (Ṭabrasī, nd: 20/290).

Tafsīr al-Tahrīir wa al-Tanwīr, based on Surah Anbiyā', verse 18, brings the second saying from the Tafsīr-i Nimūneh (Ibn Ashur, 1420 AH: 22/98). And in the Tafsīr Rūh al-Ma'anī, he quotes the first saying of Tafsīr-i Nimūneh from Qatādah, and it brings the second saying from Ibn Abbas but he does not collect between them. (Ālūsī, 1415: 11/328).

\section{Narrative examination}

Imam Ali (AS) in response to a man for whom the verses were suspicious, citing verse 48 of Surah Saba' defined "Qadhf" as throwing the word of God in the hearts of the prophets (Qomi Mashhadi, 1368: 3/591)1.

\section{Lexical examination}

The word "Qadhf" in the Qāmūs Qur'an means to drop and leave or abandon (Qarashī, 1371: 5/259) and in the Mufradāt of the Qur'an it is something can be discarded that there is distance in this word due to the meaning (Rāghib Isfahani, 1369: 661).

\section{Critique}

In Tafsīr Rūh al-Ma'ān̄, although two sayings have been mentioned, but they have not been gathered together, and in other interpretations, only one interpretation has been mentioned, and the Tafsīri Nimūneh has combined three sayings, while no strong reason has been stated for the third saying. The

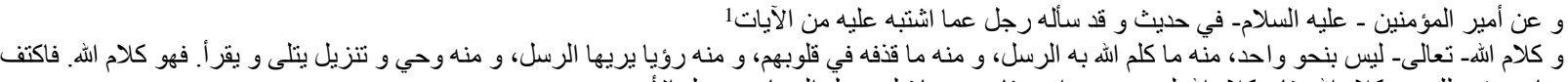

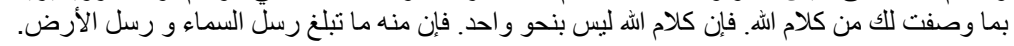


first and second statements cannot be combined. In the narrative discussion, the first view of the Tafsir-i Nimūneh is confirmed, and in the lexical discussion, although all interpretations seem possible, no argument is provided for the collection of interpretations. Therefore, Tafsīr-i Nimūneh, without having sufficient documents, is doomed to impose the sum of the sayings in this verse.

\section{5-2. The meaning of "sorrow" (Fāțir: 34)}

"And they will say:" Praise be to Allah, Who has removed from us (all) sorrow: for our Lord is indeed Oft-Forgiving Ready to appreciate (service)." (Fāțir/34)

\section{Examining the concept}

In Tafsìr-i Nimūneh, some commentators consider this sorrow to be related to the sorrows of the world, and some consider it related to the sorrows in the hereafter as the result of our deeds in this world. These two interpretations do not have contradictions and are the same in the meaning of the verse (Makarem Shirazi, 18: 270/1371).

Tafsīr al-Mīzān, like the Tafsīr-i Nimūneh, brings two sayings but does not combine them. According to Rūh al-Ma'ānī, "sorrow" means the sorrow and grief of the world, and according to Majma' al-Bayān, it means sorrow that is obtained in the Hereafter before entering Paradise because of sins (Tabataba'i, 1374: 17 / 67) and he himself does not comment.

The rest of the interpretations have quoted one case from the sayings of others. Majma' al-Bayān has brought the second saying of Tafsīr-i Nimūneh as "it was said" (Ṭabrasī, nd: 20/342) and Rūh al-Ma'ānī has quoted the first saying of Tafsīr-i Nimūneh based on the sayings of others (Ālūsī, $1415 \mathrm{AH}: 11 / 371$ ) and Tafsir al-Hadith has also quoted the second case from others (Darwazeh, $1421 \mathrm{AH}: 3 / 126)$.

\section{Critique}

Tafsīr-i Nimūneh does not state a reason for combining the two meanings, and neither of the interpretations combines the two meanings. There is no narration, based on which the sum of sayings can be accepted, as well as the meaning of grief which is the opposite of joy (Qarashī, 1371: 2/126), it seems that the sum of sayings in this verse cannot be accepted.

\section{5-3. Learning a Lesson from Seeing the Fate of the People of Lūt}

Verily, ye pass by their (sites), by day. And by night: will ye not understand? (Șāffāt/137-138)

\section{Explaining the concept of the verse}

Tafsīr-i Nimūneh has accepted "don't you think"in both the outward and inward meanings. In the literal sense it means that you always cross their land in the morning and evening, because the people of Lüt lived in the land between the Levant and the Hejaz, and the meaning of "crossing in the morning and evening" is crossing the ruins of that land. This interpretation is due to the fact that the cities of the people of Lut were on the way of the caravans of the people of Hejaz to the Levant, and these were in day and night journeys. They passed by them, if they had any ear, they would hear the heartbreaking cries of this sinful people, because the ruins of their cities taught everyone in a dumb language, and warned everyone from getting caught in the wary of similar incidents. And he cites the esoteric meaning to the narration of Imam Șādiq (AS). Imam Șādiq (AS) said about the interpretation of verse 138 of Surah As-Șāffăt: "when you recite the verses of the Holy Qur'an, you pass them, the Qur'an tells you the news that God has revealed. "In the following, the combination between the two interpretations is allowed because the works

\footnotetext{
1 "Rawḍa Kāfî" according to the "Nūr al-Thaqalayn" on the volume 4, page 432.
} 
of people of Lūt were in front of the eyes outside and its news was also mentioned in the Qur'an (Makarem Shirazi, 1371: 150/19).

Tafsīr al-Mīzān expresses the first interpretation using the appearance of the verse. (Tabataba'i, 1374: 17/247)

Majma' al-Bayān like al-Mīzān (Ṭabrasī, nd: 21/46) Tafsīr al-Tahrīir like al-Mīzān (Ibn Ashur, 1420 AH: 23/82) Rūh al-Ma'ānī like al-Mīzān (Ālūsī, 1415 AH: 12/136).

All the interpretations under discussion interpret the appearance of the verse, but the Tafsir-i Nimūneh, which brings the second interpretation from the narration of Imam Șādiq (AS), combines between the two interpretations.

\section{Critique}

Unlike other interpretations, the Tafsīr-i Nimūneh based on the narration of Imam Șādiq (AS) has combined between the apparent meaning and the hidden meaning of the verse, and since the words of Imam Șādiq (AS) are one of the examples of the verse, the opinion of the Tafsīr-i Nimūneh can be accepted in the sum of sayings.

\section{5-4. The Meaning of "Sīq" (Zumar: 73)}

And those who feared their Lord will be led to the Garden in groups: until behold, they arrive there; its gates will be opened; and its keepers will say:" Peace be upon you! Well have ye done! Enter ye here, to dwell therein." (Zumar/73)

\section{Explaining the meaning of the verse}

In Tafsīr-i Nimūneh, it has been stated that the interpretation of "Sīq" is used in cases that take place without inner enthusiasm and desire. This interpretation is correct for the inmates of Hell, but it is questionable for the people of Paradise. Some have said that the heavenly beings are waiting for their friends and are not eager to go to heaven. Some consider this interpretation to be correct because the longing to meet the Lord of the heavens has diverted attention from heaven, and some have said that their movement to heaven is fast because the angels and heaven are more eager for them. While the interpretations are good, they do not contradict each other (Makarem Shirazi, 1371: 19/554). The combination of the utterances is obvious from the point of view of the author of Tafsir-i Nimūneh, while the other interpretations studied refer to only one meaning for the interpretation of "Sīq" and that means to make it move (Tabataba'i, 1374: 17/451). Only in the interpretation of Rūh al-Ma'anī the movement is specified with speed and dignity. (Ālūsī, 1415: 12/287). In none of the interpretations studied, "Sīq" is not said to be a movement without enthusiasm or inner reluctance.

\section{Narrative examination}

In the interpretations of Qomi and Kanz al-Daqā'iq, there is no narration about the type of movement of the People of Paradise and the interpretation of "Sīq" is not mentioned.

\section{Lexical examination}

In Abjadī dictionary, Asāqa means to drive (Bustān̄̄, 1399: 50) and in the Mufradāt of the Qur'an, Sūq al-Ibil means to drive a camel (Rāghib Isfahani, 2/283) and in the Qāmūs al-Muhịṭ, "Al-Sāq" is mentioned as the time of the severity of the matter (Firuzabadi, $1415 \mathrm{AH}: 3 / 335$ ). 


\section{Critique}

Tafsīr-i Nimūneh expresses a different meaning than other interpretations. Although he writes that such a meaning is derived from other commentaries, but the name of any commentary is not mentioned as the source of this quotation, and it does not give any citation in the literal meaning and regarding the narrative interpretation. Therefore, it seems that the sum of the accepted sayings in this verse is not acceptable.

\section{5-5 Meaning of Șarșar (Ḥāqqah: 6)}

"And 'Ad people were destroyed by a Furious cold wind" (Hāqqah/6)

\section{Explaining the meaning of the verse}

In Tafsīr-i Nimūneh, it is stated that "Șarșar" is the loud and cold or poisonous winds. All three meanings have been expressed by the commentators and the combination of all three is also possible (Makarem Shirazi, 1371: 24/438). In Tafsīr Al-Mīzān commentary, "Șarșar" means very cold and strong wind (Tabataba'i, 1374: 1965/65). In Majma' al-Bayān, according to Ibn Abbas and Qatādah, it is the intensity of coldness, and according to other commentators, it is a strong wind that is higher than the famous limit (Tabrasī, nd: 25/259) and Tafsir al-Tahrīr calls it a noisy wind like Sarī and he cites verse 16 of Surah Fuș̦ilat (Ibn Ashur, 1420 AH: 29/108).

\section{Narrative examination}

In a narration from Abi Jārūd from Abi Ja'far (AS) in the interpretation of verse 6 of Surah AlHāqqah, it is stated that the wind is cold in the days of misfortune (Ali Ibn Ibrahim, 1363: 2/298) ${ }^{1}$ and in a narration of Ali Ibn Hussein that God saved Hūd and those who were with him and destroyed the people of 'Ād with a barren wind (Qomi Mashhadi, 1368: 5/117). In a narration of Imam Ṣādiq (AS), it has also been interpreted as a barren wind (Ibid: $11 / 437)^{2}$.

\section{Lexical examination}

In Tāj al-Arūs, the barren wind is considered as the wind with which the people of 'Ād were perished (Hussaynī Zubaydī, 1414 AH: 4/1988), and in Shams al-Ulūm, Șarșar is considered as the wind in which there is a loud sound (Humayrī, 1420 AH: 6/3633). In Qāmūs al-Qur'an, it is a strong or very cold wind (Qarashī, 1371: 4/122).

\section{Critique}

Sayings can be summed up according to the proximity of the meanings, and the interpretive narratives that implies all the meanings, and the dictionaries that cover all the interpretations.

\section{5-6. Tafsir "the Rising by Night" (Muzzammil: 6)}

Truly the rising by night is a time when impression is keener and speech more certain. (Muzzammil/6)

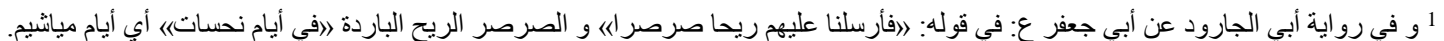

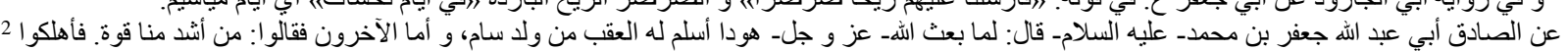
بالريح العقيم، و أوصادم هو الهد و و بشر هم بصالح- عليه السلام.
} 


\section{Examining the meaning of the verse}

In Tafsīr-i Nimūneh for interpreting "the rising by night", three sayings have been given: first, meaning the last hours of the night and dawn, second, rising for prayer and recitation of the Qur'an according to a narration of Imam Bāqir (AS) and Imam Șādiq (AS), and third, spiritual states and divine vitality that is raised in human beings in these hours of the night with more deep effect, it is appropriate for the meanings to be combined together (Makarem Shirazi, 1371: 25/175). Tafsīr al-Mizan refers to night because it refers to the event as night, just as it refers to the components of creation (Tabataba'i, 1374: 20/99).

Tafsīr Majma' al-Bayān quotes Ibn Abbas as saying, it means all night because it comes after the day. According to Aisha, it is waking up after sleep. According to Hassan and Qatādah, it is the stand up after the evening prayer and according to the narration of Imam Bāqir (AS) and Imam Șādiq (AS), it is the stand up at the end of the night until the night prayer (Ṭabrasī, nd: 26/21).

Tafsir al-Tahrīir like Al-Mīzān (Ibn Ashur, 1420 AH: 29/244) Tafsir Rūh al-Ma'ānī like Majma' al-Bayān (Ālūsī, 1415: 15/117).

\section{Lexical examination}

In the Mufradāt Qur'an, it is stated:

Truly the rising by night is a time when impression is keener and speech more certain. (Muzzammil/6) namely one rises at night to say prayers. (Raghib Isfahani, 1369: 807)

And somewhere else it is stated that Nash'at means creating something and educating it (Ibid: 4/339).

\section{Critique}

Although a few quotations have been made in the Tafsīr Majma' al-Bayān, they have not been collected and other commentaries have mentioned only one commentary. There is no semantic diversity in the word and there is no argument for the collection of sentences in Tafsīr-I Nimūneh.

\section{5-7. Interpretation of Food ('Abasa: 24)}

Then let man look at his food, (and how We provide it) ('Abasa /24)

In Tafsīr-I Nimūneh, according to the appearance of the verse, he interprets "food" as the food of the body and considers it halal and haram and legitimate and illegitimate with the obligatory meaning. But according to the narrations of the Infallibles (AS), he also considers "food" as science and knowledge. For example, it has been narrated from Imam Bāqir (AS) that in the interpretation of this verse, he said: علمه لخه (AS) (Makarem Shirazi, 1371: diq ậ" "The same meaning has been narrated from Imam 1 الذى ياخذه عمن ياخذه 26/146).

Tafsir al-Mīzān, according to the first Fà ${ }^{\prime}$ of the verse, which is a branch of the previous sentences, and that interpretation is the elaboration of consensus, and pays attention to the general human beings, considers the food of the body suitable. Man, considering the millions of blessings that he has around him, by studying in this part, observes the divine plan (Tabataba'i, 1374: 20/341).

${ }^{1}$ Tafsīr Burhān, v. 4, p. 429. 
The interpretation of Majma' al-Bayān is similar to the interpretation of Al-Mīzān (Ṭabrasī, nd: 26/312) as well as the interpretation of Rūh al-Ma'ānī (Ālūsī, 1415 AH: 15/248).

\section{Critique}

The only reason for the Tafsīr-i Nimūneh to combine the two interpretations is the narrations of the infallibles, which can be an example of the verse.

\section{5-8. Tafsir "Ahl" (Inshiqāq: 9)}

And he will turn to his people, rejoicing! (Inshiqāq/9)

Various interpretations have been expressed for "Ahl", including his faithful wife and children or the Houris or faithful people who were dear to him in the world and he goes on to say that the combination of these meanings is possible (Makarem Shirazi, 1371: 26/303).

Allameh in Tafsīr Al-Mīzān, according to the context, refers to the people as Houris who have come to him in paradise and considers two other cases as unlikely (Tabataba'i, 1374: 20/402).

In Tafsīr Majma' al-Bayān, the author considers his opinion as in Al-Mīzān, namely the heavenly wives, and expresses the other two opinions in the form of quotations, but he does not accept them and does not gather between them (Tabrasī, nd: 26/396).

Tafsīr Rūh al-Ma'ānī, like Majma' al-Bayān, interpreted Ahl as the heavenly wives (Ālūsī, 1415 AH: 15/289).

\section{Narrative examination}

In a narration of Imam Bāqir (AS), he said: I heard my father say that Ahl in verse 9 of surah Inshiqāq are his people in this world who will be his people in Paradise (Bahrānī, 1415 AH: 5/618) ${ }^{1}$.

\section{Critique}

The only reason that Tafsīr-i Nimūneh provides for the sum of sayings is the narrations that indicate this meaning. Therefore, for example, the sum of sayings in this interpretation is acceptable.

\section{5-9. Interpretation of "a Distinguishing Word" (Ṭāriq: 13)}

Behold this is the Word that distinguishes (Good from Evil): (Ṭāriq/13)

\section{Examining the meaning of the verse}

In Tafsīr-i Nimūneh, "a distinguishing word" is a word that distinguishes between right and wrong, but according to the analogy of the previous verses, some consider it as resurrection and some as the Qur'an. In a hadith from Amir al Mu'minin Ali (AS) has been quoted from the Holy Prophet of Islam who said: "Soon a sedition will appear among you. I said: O Messenger of God! What is the way to save from it? said: It is the Qur'an, which tells the news of the ancients, and of future ages and it is a judge among you; it is the word that separates truth from falsehood, it is serious and not a joke, every cruel who leaves it, God will crush him, and whoever seeks guidance other than it God misleads him! ${ }^{2}$

$$
\begin{aligned}
& \text { الحسين بن سعيد في كتاب (الز هد): عن القاسم بن محمد، عن علي، قال: سمعت أبا عبد الله (عليه السلام) يقول.... قلت: أب أهل؟ قال: 》أهله في الدنبا هم أهله في }
\end{aligned}
$$

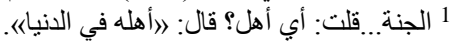

${ }^{2}$ Ṣahīh Tirmidhī and Sunan Darimi according to Tafsīr Rūh al-Ma'ān̄̄, v. 3, p. 100 and Tafsīr Marāqī v. 30 , p. 118. 
He goes on to write that the interpretation of the Day of Separation in Resurrection is very prominent in the Qur'an, and even if this interpretation is for the purpose of the Qur'an, the verses of the Qur'an announce the resurrection, so there is a combination between the two interpretations (Makarem Shirazi, 1371: 26/374).

Allameh writes in Tafsīr al-Mīzān that Faṣl means the separation of two things in such a way that there is a distance between the two. "a distinguishing word" means the Qur'an and was read as "Zayd-e'Adl".

In Tafsīr Majma' al-Bayān, the author first expresses his opinion and writes that the Qur'an distinguishes between right and wrong and cites this interpretation to a narration from Imam Șādiq (AS) and then quotes other commentators who interpret the "a distinguishing word" on the Day of Judgment (Ṭabrasī, nd: 27/13).

Tafsīr al-Tahrīr considers the Qur'an as the separator between right and wrong (Ibn Ashur, 1420: 237-30) and Rūh al-Ma'ānī, like Tafsīr al-Tahrīir, introduces the "a distinguishing word" as the Qur'an (Ālūsī, 1415 AH: 15/311).

\section{Critique}

The interpretation of the "separating promise" to the resurrection exists only in Tafsīr-i Nimūneh. And the reason for that is mentioned in the interpretive narrations which can be examples of the verse, so the sum of the two sayings in Tafsīr-i Nimūneh is understandable.

\section{Conclusion}

The results of this study, which dealt with the view of the sum of sayings in Tafsir-i Nimūneh, indicate the need to critique and pay attention to this view in this interpretation. The high repetition of the sum of the sayings in Tafsīr-i Nimūneh required research and study of this method. In the studies conducted, the sum of the sayings in Tafsīr-i Nimūneh is in three forms. In the first group, the sayings have been collected, but none of them has been selected or rejected, and no collection has taken place among them. The author does not seem to accept either. The second group, a few sayings have been mentioned, but one of them, usually with documentation, is selected and the task of the reader is clarified. In the third group, which is discussed in this section, it includes the sayings that have been collected together, and the author considers their collection as allowed or possible, in other words, he accepts all or some of them.

Comparing the verses of the third category with the other five interpretations, it can be concluded that there is the most similarity in the sum of the sayings in the interpretation of Majma' al-Bayān and then Al-Mīzān with the Tafsīr-i Nimūneh. It is important to note that these two interpretations, except for a handful, have only mentioned the sayings, but have not collected them. In other interpretations, except in a limited number of cases, the sayings have not been accepted. This needs a critique of views of sum of sayings in Tafsīr-i Nimūneh.

In a number of verses, acceptance of the sum of the sayings is imposed on the verse, and it seems that there were not enough documents for this acceptance, such as (Saba': 48), (Fāțir: 34), (Zumar: 73) and (Furqān: 6) and in a number of verses, the sum of the sayings are accompanied by documents and are acceptable, such as (Șāffāt, 137 and 138), (Hạāqah: 6), ('Abasa, 24), (Inshiqāq, 9) and (Ṭāriq, 13). 


\section{Bibliography}

The Holy Qur'an

Ālūsī, Mahmoud ibn Abdullah (1415 AH). Rūh al-Ma'ānī fi Tafsīr al-Qur'an al-Azim wa al-Sab' alMathānī, Lebanon: Beirut, Dar al-Kutub al-Ilmīyyah Manshurat Muhammad Ali Bayḍūn.

Bahrānī, Hāshim ibn Sulaymān. (1415 AH). Al-Burhān fi Tafsīr al-Qur'an, Al-Bi'thah Institute, Islamic Studies Department, Iran - Qom, first edition.

Bustān̄̄, Fu'ād Afrām. (1399 HS). Farhang Abjad̄̄, Tehran: Islamic Publications.

Darwazeh, Mohammad Izza (1421 AH). Al-Tafsir al-Hadith: Arrangement of Surahs according to revelation, Lebanon-Beirut, Dar al-Gharb al-Islāmī, second edition.

Firuzabadi, Muhammad ibn Ya'qub (1415 AH). Qāmūs al-Muhīṭ, Beirut-Lebanon, first edition.

Ḥumayrī, Nashwān ibn Sa īid. (1420 AH). Shams Al-Ulūm wa Dawā‘ al-Kalām al-Arab min al-Kalum, Damascus-Syria.

Ḥussaynī Zubaydī Wāsițī, Seyyed Morteza. (1414 AH). Tāj al-Arūs min Jawāhir al-Qāmūs, BeirutLebanon, First Edition.

Ibn Ashur, Muhammad Tahir. (1420 AH). Al-Taḥrīr wa al-Tanwīr al-Ma rūf bi Tafsīr Ibn Ashur, Lebanon: Beirut, Institute of Arab History, first edition.

Makarem Shirazi, Nasser. (1371 HS). Tafsīr-i Nimūneh, Iran-Tehran, Islamic Library.

Qarashī Bonabi, Seyyed Ali Akbar. (1371 HS). Qāmūs Qur'an, Islamic Library Publications, Tehran.

Qomi, Ali Ibn Ibrahim (1363 HS). Tafsir al-Qomi, Dar al-Kitāb, Iran - Qom, third edition.

Qomi Mashhadī, Mohammad ibn Mohammad Reza (1368 HS). Tafsīr Kanz al-Daqā’iq wa Bahr alGharā'ib: Iran-Tehran, Ministry of Culture and Islamic Guidance. Printing and Publishing Organization, First Edition.

Rāghib Isfahani, Hassan ibn Mohammad. (1369 HS). Translation and research of Qur'anic words, translated by Gholamreza Khosravi Hosseini, Iran-Tehran.

Tabataba'i, Mohammad Hussain (1374 HS). Translation of Tafsir al-Mīzān; Translator: Mohammad Bāqir Mūsawī, Qom Seminary Teachers Association, Islamic Publications Office, Iran-Qom.

Ṭabras̄̄, Faḍl Ibn Hassan (nd). Translation of Tafsir Majma' al-Bayān; Translator: Hossein Nouri Hamedani, Farahani, Iran, Tehran.

\section{Copyrights}

Copyright for this article is retained by the author(s), with first publication rights granted to the journal.

This is an open-access article distributed under the terms and conditions of the Creative Commons Attribution license (http://creativecommons.org/licenses/by/4.0/). 